of his political party at their weekend meeting on the slopes of Mount Fuji two weeks ago. It seems, however, that he said (in English) that Japan is an "intelligent society" and that the United States, in some sense of the phrase, is less so on account of the "minorities" it includes. Mr Nakasone has apologized to anybody who have thought he meant to say that minorities in the United States, black or otherwisc, are in some sense inferior to Japanese. Of necessity, he has not withdrawn the nub of his assertion that there is something special about Japan. This truth, of course, is widely recognized as such; even if the pace of economic growth has slackened in the past few years, Japan's economic transformation in the past 40 years counts as a realworld miracle. But is it also possible that Mir Nakasone has been unduly influenced by the report by $\mathrm{R}$. Lynn four years ago (Nature 297, 222; 1982), suggesting that the improvement (increase) of the IQ of children in Japan in the years since the Second World War had been more rapid than that among schoolchildren in the United States during the same period? Lynn's study was widely reported in Japan when it appeared.

Next to the rapid economic growth of recent decades, almost the most remarkable feature of Japanese society is its selfconscious regard for its standing in the eyes of others. No doubt this curiosity stems in part from the general knowledge that almost within living memory, Japan was a closed society, with hardly any links with the rest of mankind, which accounts for its racial and cultural homogeneity (some vociferous Koreans notwithstanding).

Prudent commentators also note three features of modern Japan of which Mr Nakasone is well aware. First, people's devotion to the education of their children is literally unparalleled; the participation in higher education is no less than 36 per cent. Second, Japan has not spent much time or resources on the development of social services, with the consequence that the disadvantaged are literally so, while those still at work save all they can against the time when the calamity of retirement strikes them (which is why capital investment is so high). Then, third, Japan is in many ways an inefficient economic system, with a distribution system employing many more people than would be needed in most other parts of the world (which may compensate for the lack of social security), urban roads perpetually clogged with traffic and urban trains perpetually crammed with people travelling to and from their work.

What Mr Nakasone should have said, and what it must be presumed he meant to say, is that the most distinctive feature of modern Japan that distinguishes it from the United States is the zeal with which education is pursued. Because, these days, nobody supposes that measured IQ is an unchangeable attribute of individuals, Japanese education may, by itself, account for the findings reported by Lynn four years ago. But that does not imply that Japan's advantage could be easily repeated elsewhere; cost apart, this generation's education is also an investment in its successor. Japan's homogeneity, cultural and ethnic, may be less of an advantage than the common denominator of Nakasone's remarks implied; does anybody at this stage doubt the effectiveness of the melting pot of the United States in the later nineteenth century as an engine of economic and social development? The only simple ways of comparing complicated societies are by definition simplistic. Maybe $\mathrm{Mr}$ Nakasone meant to say that as well?

\section{Death of a submarine}

\section{The loss of a Soviet nuclear submarine is a remin- der of the seriousness of the world we live in.}

Tirf good news first. Just two weeks ago, most governments with pretensions to nuclear power, military or otherwise, put their names to two conventions negotiated during August, in the aftermath of the Chernobyl accident, which among other things require that those responsible for nuclear accidents should promptly let others know. The language of the conventions is such that military accidents may or may not be covered; much depends on how those responsible decide to interpret the documents they have signed in the light of the circumstances in which they find themselves. On this latest occasion, the Soviet Union has done everything that might be expected of it. The United States was told there had been an accident on board a nuclear submarine a few hours after it had happened. The Soviet authorities have also said that the reactor that had driven the vessel had been shut down before the ship was scuttled. The nuclear weapons on the vessel will finish up on the deep ocean bed, where their load of fissile material will be released in the course of the next few years, thus providing an unwitting test of claims that sea-bed disposal is safe. (Two other Soviet submarines have been lost on carlier occasions, but so far as can be told they have not yielded detectable contamination.) The International Atomic Energy Agency, to which Chernobyl gave a new lease of life, can hardly have hoped there would have been such a quick and successful test of people's willingness to adhere to its conventions on nuclear accidents that have international implications.

The bad news (but that is also good news in one sense) is that a Soviet submarine built for attack should have run into trouble a few hundred miles from the eastern seaboard of the United States. That is a reminder, also timely, of the role that nuclear deterrence plays in the present strategic balance. A little thought, of course, will show that the western mid-Atlantic is one of the places in the oceans at which Soviet submarines would be stationed. There will be others off the Pacific coast, just as there will be US (and perhaps even French and British) nuclear submarines in the western Pacific and the North Atlantic. Submarines, of course, are less conspicuous than land-based strategic missiles, which have in any case attracted most attention in the past decade because of the concentration of novel types in Europe. But the secretiveness of submarines is also their strategic strength, recognized by all sides, which is why their abolition is not on the agenda at this weekend's hasty meeting in Reykjavik. During the negotiation of the present Strategic Arms Limitation 'Treaty (SALT II), the United States was even pressing for a greater reliance on submarines. Whatever happens next weekend, they will continue to lurk off people's vulnerable coastlines at least until they can be spotted there more easily than at present. (Some people would give that ten years, but realists see more future in submarines.)

This has a bearing on the debates in the past few weeks on the role of nuclear weapons in the defence of Europe. Even though the next general election may be as much as eighteen months away, British voters have on offer a spectrum of policies from which to choose. The government is at one end and the Liberal Party (inconveniently half of the association with the Social Democratic Party (SDP) called the Alliance) at the other. The Labour Party would get rid of other people's nuclear weapons, and maybe even those it would inherit if elected; the SDP would keep nuclear weapons as such, but not buy the new Trident nuclear submarines, seeking some nuclear alliance with France instead. For good measure, the Labour Party would also "phase out" civil nuclear power stations, most probably by letting those now in service come to the ends of their working lives.

In a curious way, all these positions are given the character of charades by the sinking of the Soviet craft north of Bermuda. Nobody supposes that the loss of a single nuclear vessel will take the edge off Soviet strategic power, but such an event would quickly make the threat posed by the smaller forces seem the opposite of what it is meant to be - credible. Both Britain and France could make a lot of mischief with their existing nuclear forces if the big boys allowed them to do so. But because the chance of that happening is small, even declarations that unilateral disarmament will provide an example for others seem puny gestures. Should not these smaller nuclear powers at least decide more clearly than they have done so far what these dangerous weapons are for? 